\title{
A Cognitive Semantics Analysis of Wolio Proverbs Related to the Human Body
}

\author{
Firman Alamsyah Mansyur ${ }^{1 *}$, Ratna Said ${ }^{1}$
}

\author{
${ }^{1}$ Indonesian Language and Literature Education, Universitas Muhammadiyah Buton, Baubau, Indonesia \\ *Corresponding author. Email: firman.alamsyah@umbuton.ac.id.
}

\begin{abstract}
Proverbs are expressions of language that show a close relationship between language, culture, and human cognition. Therefore, this paper aims to explain the cognitive mechanisms that cause humans to form proverbs that use their body from a cognitive linguistic point of view. The method used is a qualitative method. The data was taken from a collection of Wolio proverbs and then identified and mapped the source and target domains based on metaphorical and metonym concepts. The results showed that the mapping of human body in Wolio proverbs contained images of positive, negative, and neutral meanings. The meaning of the human body not only had a specific meaning that indicated the cultural experience of an ethnic but also showed the generality that indicated the spread of proverbs from one culture to another. The mechanism of metonym was the role of moving specific parts of the human body to the nature or behavior of humans in general. This finding confirmed the differences and similarities of metaphorical propositions and schemes in the semantic of the human body proverb.
\end{abstract}

Keywords: cognitive semantics, Wolio proverbs, metaphor, metonym

\section{INTRODUCTION}

Proverbs are expressions of language and human thoughts that contain the values of wisdom of a tribe in understanding the world around them. Mieder [1] said that proverb is a short sentence that "contains wisdom, the truth, moral, and traditional views in a metaphorical and memoizable form and which is handed from generation to generation." Therefore, the existence of proverbs is very important. Proverbs not only arise as a result of human observations of natural phenomena [2], but are also born from human observations and contemplations of their own body. The discussion of the human body proverb becomes interesting to be seen in a cognitive semantic perspective because its existence in the view of the Great Chain of Beings Metaphor is part of the human self but is used as a realm of resources to describe the nature and behavior, and the human condition itself.

Evans and Green [3] explain that cognitive semantic studies aim at examining concept formation, semantic structure, representation of meaning, and formation of meaning. Lakoff and Johnson [4] propose a conceptual metaphor analysis model that emphasizes three aspects, namely: source domain, target domain, and a set of mapping relations or correspondences. Besides that, Lakoff and Turner [5] also suggest the Great Chain of Being Metaphor Theory (GCMT) to understand the problem of cognition in proverbs well. According to Kovecses, the Great Chain of Being Metaphor theory examines how everything is interconnected in the world. A proverb can be metaphorical when a creature at a certain level is used to conceptualize a creature at another level [6].

The study of proverbs in the cognitive semantic view has been widely studied, however, the study of proverbs in the human body is still not widely found. Ho-Abdullah [7] examined Malay proverbs that came from dogs with a cognitive semantic approach. The study explains that dogs in Malay proverbs are perceived as weak, despicable, and unskilled people. This is different from the prevailing mapping in English proverbs where dogs are perceived as obedient and loyal humans. This study shows that different cultures and people's experiences in interacting with animals, especially dogs, will form different cognitive models that are reflected in the language proverbs.

Sameer [8] conducted a comparative study of horse and dog proverbs in English and Arabic. This study concludes that the proverb data of the two languages show the same purpose and meaning. Dogs and horses in both languages have the same or close semantic molecules even though proverbs are the result of social values and cultural values. This shows the process of mental mechanisms, metonymy, and the same metaphor.

Nugraha [9] also studied proverbs in a semantic cognitive perspective. From his study, he explained that in general the classification of animals in Javanese proverbs can be divided into five categories, namely: (a) ingon-ingonan, (b) alasan, (c) satoan, (d) buron, and (e) pangirid. From this study, an understanding of the three wisdoms in the classification of animals is obtained, do not kill every living thing, do not damage anything, and do not eat animals.

On the other hand, Noverita [10] analyzed the meaning of the classic Minangkabau proverb by using a semantic perspective. From the results of her study obtained an understanding model that the classic Minangkabau proverb illustrates the close relationship between adat and sharak in the life of the Minangkabau people. Minangkabau people 
really hold customs and traditions that are based on true islamic teachings and they must live in their lives.

Contrary to previous studies, this study analyzes cognitive mechanisms in proverbs related to members of the human body. Hierarchy of creatures that have been used as a conversation in various studies of proverbs still used but the focus is different. This study focuses on humans as a central point. How Wolio people perceive their body and experiences into something quite different from the perception of animals' proverbs. In addition, the semantic cognitive study in this study also not only focuses on linguistic structure, but reveals background knowledge, and cultural aspects in a proverb.

\section{RESEARCH METHODS}

This research is a qualitative research model. The data were taken from a collection of Wolio proverbs written by Mansyur [11]. Proverbial data related to the human body were identified and analyzed by mapping which parts are the source domain, target domain, and a set of mapping relations or correspondence as the view of Lakoff \& Turner [5]. In addition to the analysis of the conceptual metaphors above, the Concept of the Great Chain of Being Metaphor, and the metonymy of GENERIC REPRESENTATIONS as Lakoff \& Turner [5] and Kovecses [6] also used to understand the meaning of proverbs. From this description, conclusions can be drawn as a semantic cognitive understanding model for the proverbial Wolio, which is a member of the human body.

\section{RESULTS OF ANALYSIS AND DISCUSSION}

Based on the analysis found that there are five proverbs that use the outside of the human body to conceptualize human behavior, traits, circumstances, or feelings themselves. Wolio proverbs that use the human body as a source of inspiration can be explained as follows in cognitive semantic perception.

\subsection{Binci-binciku kuli!}

$\begin{array}{ccc}\begin{array}{c}\text { 'Pinch a little skin!' } \\ \text { Source Domain } \\ \text { binci-binciki } \\ \text { to pinch a little } \\ \text { kuli 'skin' }\end{array} & ----->\begin{array}{c}\text { Target Domain } \\ \text { hurts, feels }\end{array} \\ & -----> & \text { human heart }\end{array}$

The proverb above implies a prohibition against hurting others. The word kuli 'skin' is mapped with human hearts or feelings so that the meaning of the proverb is forbidden to hurt human feelings. In this case, the skin is the outer layer of the human body that is very sensitive to external stimulation, so the skin represents human feelings that are abstract and general. The mechanism used is that specific metonymy is generic, that is, specific things that represent the general, or from concrete to abstract. This is in line with the views of Lakoff \& Turner [5] which emphasizes the semantic interpretation of proverbs in the metonymy model, SPECIFIC REPRESENTATIVES GENERIC. Besides that, the proverb has a positive meaning so that humans feel the feelings of others so that he/she can maintain his/her behavior and words in building social relationships with others.

\subsection{Amasodo ngangana.}

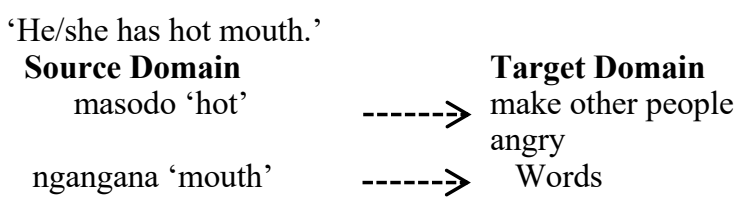

The proverb above generally means a person who if he/she does not speak carefully so that he / she can offend others or make other people angry. In the proverbs above, the word ngangana 'mouth' is mapped or perceived with words because one of the functions of the mouth is to help humans in making sounds that contain meaning or words. In addition, masodo 'hot' is interpreted as heat or uncomfortable so that it can quickly make other people's moods become angry. Even though the word ngangana 'mouth' does not contain negative meaning, a person whose mouth is hot is not meant to be good because it can cause dissension with others. Therefore, this proverb contains negative meanings or messages to others.

\subsection{Apati biwina.}

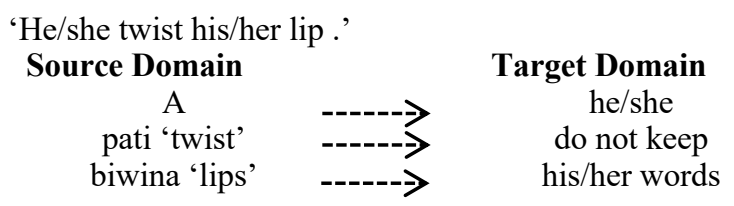

The proverb above is generally interpreted by people who do not keep their words or promise. In this expression, biwina 'lips' is mapped as words because the lips also help in the process of producing words. Meanwhile, the word pati 'twist' is interpreted by not keeping it because in cultural cognition the person who twist is associated with changing the direction of the path that he / she is using. This proverb contains negative meanings or messages of advice that must be avoided. If we look closely, the mouth and lips in the Wolio proverb are used for the same purpose, namely words. Wolio people pay great attention to the use of lips and mouth for good purposes. The basic conceptualization of the expression is based on the function of the lips in general for humans, but the use of the adjective "hot" makes the expression negative. Therefore, the noun "lip" whose meaning is neutral becomes changed due to the use of the adjective "hot". This conceptualization is greatly influenced by the experience of Wolio people in interacting with fellow humans or their environment. 


\subsection{Marido yi mata, makasu yi totona yinca.}

'Far from the eyes, close to the heart.'

$\begin{array}{lll}\begin{array}{l}\text { Source Domain } \\ \text { marido yi mata }\end{array} & \begin{array}{l}\text { Target Domain } \\ \text { rarely meet }\end{array} \\ \text { 'far from the eyes' } & ----->\text { rasu yi totona } & ------>\text { often missed } \\ \text { makasu } \\ \text { yinca } \\ \text { 'close to the heart' }\end{array}$

The above proverb generally contains the meaning of people who are always missed. In this phrase, far from the eyes is mapped as people who are rarely seen so rarely meet. The noun "eye" is a human organ that functions to see other people so that the phrase "far from the eye" is meant to be never seen. Meanwhile, close to the heart is meant by people who are longed for because of the public perception that the human heart is a place of longing. The noun "heart" is conceptualized with feelings so that being close to the heart means often missed. The phrase is generally positive because it is an expression that can strengthen the relationship of two individuals. The phrase has a closeness of meaning to the Indonesian proverb "far in the eyes, close to the heart". But it has a different meaning with the English proverb that reads "Far from eyes, far from heart". However, the construction has something in common. The English proverb emphasizes that distance makes a person forget his/her friend.

\subsection{Boli palapasi awaamu!.}

'Don't strip off of your shoulder!'
Source Domain boli

'do not'

palapasi

'strip off'

awaamu

'shoulder'

\section{Target Domain}

do not

strip off

responsibility
The above proverb generally implies that a person should be responsible for whatever he/she does. The word boli 'don't' and palapasi 'strip off' contain literal meaning. The word awaamu 'shoulder' in the phrase is mapped as responsibilities because the function of the shoulders for Wolio people was in the past to carry heavy object. Meanwhile, responsibility is something abstract that is associated with the word bear too. Concrete mechanism to abstract applies in this proverb. In addition, this expression contains a neutral meaning depending on the context of its use, because it can contain a message of advice so that someone becomes a person who always carries out his/her responsibilities but can also mean a person who does not carry out his/her responsibilities.

From the analysis of the data above, it can be understood that the process of cognitive mechanism in the formation of proverbs that features the human body is closely related to the experience and culture of the Wolio people. Wolio people conceptualize parts of the body in different ways from other ethnicities, such as the shoulder. However, some human organs are also perceived to be the same as other cultures, such as the eyes and mouth. In addition, the conceptualization model from concrete to abstract or metonymy models is also always found in Wolio proverbial studies as well as studies [5], [6], [7]). This shows that in general the proverbs are formed by the same cognitive mechanism process, but the way to express can be different because it is influenced by different experiences and cultures.

\section{CONCLUSION}

The discussion of proverbs above can be concluded that several things related to cognitive mechanisms in the Wolio proverbs are sourced from members of the human body. In this study, an understanding model is obtained that the members of the human body have different conceptual meanings from one another. If we use the concept of metonymy SPECIFIC REPRESENTING THE GENERIC, then we can understand that the human body as a specific part are used to describe humans in general. In addition, the model of meaning transfer from something concrete to something more abstract applies also in this study. Human body parts can be positive, negative or neutral. This pattern basically shows different metaphorical propositions and schemes between cultures. Human experience in different spaces gives space to conceptualize the world in different ways. However, this study also reveals the existence of a human body metaphor in proverbs that are universal without being bound by culture. This is allegedly due to the spread of proverbs from Malay culture to Wolio culture, as in the history of Wolio explained that the influence of Malay is very strong for the life of Wolio people.

Finally, it is important to emphasize that this cognitive semantic study only finds proverbial data from a small number of the human body. Future studies can be revealed through more prominent aspects in the Wolio proverb, for example, proverbs that use plant, living tools or the environmental elements.

\section{ACKNOWLEDGMENT}

This research is supported by Institute for Research and Community Service, Universitas Muhammadiyah Buton.

\section{REFERENCES}

[1] W. Mieder, Proverbs: A Handbook. London: Greenwood Press. 2002.

[2] R. A/P. Ragavan and C. I. H. Salleh, "Peribahasa Melayu dan Peribahasa Tamil dari Aspek Sosial," Journal of Business and Social Development, vol. 3, pp. 66-75, March 2015.

[3] V. Evans and M. Green, Cognitive Linguistics. Edinburg: Edinburg University Press Ltd, 2006. 
[4] G. Lakoff and M. Johnson, Metaphor We Live By. London: The University of Chicago Press, 1980.

[5] G. Lakoff and M. Turner, More than Cool Reason: A Field Guide to Poetic Metaphor. Chicago: University of Chicago Press, 1989.

[6] Z. Kovecses, Metaphor: A Practical Introduction. New York: Oxford University Press, 2002.

[7] I. Ho-Abdulah, “Analisis Kognitif Semantik Peribahasa Melayu Bersumberkan Anjing (Canis Familiaris)," Gema OnlineTM Journal of Languange Study, vol. 11, pp.125-139, 2011.

[8] I. H. Sameer, “ A Cognitive Sudy of Certain Animals in English and Arabic Proverbs: A Comparative Study," International Journal of Languange and Linguistics, vol. 3, no. 5, pp. 133-135, November 2016.

[9] D. S. Nugraha, “The Lexicon of Animal Classification in Javanese: A Cognitive Semantic Approach," International Jounal of Humanity Studies, vol. 2, no. 2, pp. 186-195, March 2019.

[10] D. Noverita, "Semantic Analysis of The Minangkabau Classical Proverb Based on The Model of The Proverb Tree," International Journal of Linguistics, vol. 10, pp. 108-121, February 2018.

[11] F. A. Mansyur, Peribahasa Wolio: Ungkapan Kearifan Para orang Tua Dahulu. Yogyakarta:

Komojoyo Press, 2017. 